\title{
Pepper (Capsicum ssp.) as a feed additive in sheep rations using two types of inoculum: Effects on in vitro digestibility and fermentation parameters
}

\section{Pimenta (Capsicum ssp.) como aditivo alimentar em rações de ovinos utilizando dois tipos de inóculo: Digestibilidade in vitro e parâmetros de fermentação}

\author{
Luiz Juliano Valério Geron ${ }^{1 *}$; Alexandre Lima de Souza ${ }^{2}$; Suellem Fernanda Perosa \\ Zanin $^{3}$; Sílvia Cristina de Aguiar ${ }^{1}$; Ilda de Souza Santoss; Rayane Fernandes da \\ Silva ${ }^{4}$; Jocilaine Garcia ${ }^{1}$; Anderson de Moura Zanine ${ }^{5}$; Leomar Custodio Diniz ${ }^{6}$; \\ Daniele de Jesus Ferreira ${ }^{5}$
}

\begin{abstract}
The influence of pepper (Capsicum ssp.) as a feed additive to balanced sheep rations on the in vitro digestibility coefficient of nutrients and their fermentation parameters was evaluated in two different inocula: rumen liquid and sheep feces. Four inclusion levels of pepper $(0.0 \%, 0.2 \%, 0.4 \%$ and $0.6 \%$ of $\mathrm{DM}$ ) and two types of inoculum were arranged in a $4 \times 2$ factorial arrangement, in a completely randomized design. Experimental rations were balanced to include $0.0 \% ; 0.2 \% ; 0.4 \%$ and $0.6 \%$ Capsicum ssp., with $13.5 \%$ crude protein and $70.0 \%$ total digestible nutrients (TDN). A basal diet of $60 \%$ bulk (corn silage) and $40 \%$ of the concentrate containing $0.0 \%$ Capsicum ssp. was given to the inoculant donor animals. Two sheep with a mean bodyweight of $27.6+1.6 \mathrm{~kg}$ were used as inoculum donors (ruminal fluid and feces) for the determination of the $I V \mathrm{DC}$ of nutrients. The variables studied were submitted for analysis of variance and the inclusion levels of pepper. Regression analysis was performed at $5 \%$ of probability and for the different inocula, a Tukey test was performed at $5 \%$ significance. The different levels of inclusion of pepper $(0.0 \%, 0.2 \%, 0.4 \%$, and $0.6 \%)$ in the balanced sheep rations were not altered $(\mathrm{P}>$ 0.05 ) the IVDC of DM; OM; CP and NDF for both inocula (ruminal fluid and sheep feces). However, the use of the different inocula resulted in a change $(\mathrm{P}<0.05)$ in the $I V \mathrm{DC}$ value of DM, OM, CP, and NDF, in which the ruminal liquid inoculum presented higher $(\mathrm{P}<0.05)$ values of $I V \mathrm{DC}$ for the ration nutrients in relation to sheep feces. The levels of $0,0 \% ; 0.2 \% ; 0.4 \%$ and $0.6 \%$ of pepper in ruminant feeds did not change the $\mathrm{pH}$ value of the fermented content after a 24-hour in vitro incubation $(\mathrm{P}>0.05)$. However, the use of ruminal liquid as inoculum for the in vitro fermentation of the experimental rations provided a lower value $(\mathrm{P}<0.05)$ for the $\mathrm{pH}$ of the fermented content in relation to the sheep feces. The inclusion of this phytogenic additive in ruminant feeds and the use of inoculum based on rumen fluid or sheep
\end{abstract}

\footnotetext{
1 Profs., Universidade do Estado de Mato Grosso, UNEMAT, Pontes e Lacerda, MT, Brasil. E-mail: ljgeron@unemat.br; scaguiar@ unemat.br; jo@unemat.br

2 Prof., Universidade Federal de Mato Grosso, UFMT, Cuiabá, MT, Brasil. E-mail: alexandre@ufmt.br

3 Discente de Pós-Graduação em Ciências Animal, UFMT, Cuiabá, MT, Brasil. E-mail: suellemfpzanin@gmail.com

4 Discente de Bacharelado em Zootecnia, UNEMAT, Pontes e Lacerda, MT, Brasil. E-mail: ildasouza20@hotmail.com; rayzoot@ gmail.com

5 Profs., Universidade Federal do Maranhão, UFMA, Chapadinho, MA, Brasil. E-mail: anderson.zanine@ibest.com.br; dany_ dosanjos@yahoo.com.br

6 Discente de Pós-Graduação em Ciências Animal, Universidade Estadual do Oeste do Paraná, UNIOESTE, Campus de Marechal Cândido Rondon, PR, Brasil. E-mail: leomarfig@hotmail.com

Author for correspndence
} 
feces did not cause changes in the concentration of ammoniacal nitrogen (N-NH3) in the fermented rations after incubation $(\mathrm{P}>0.05)$ for 24 hours in vitro. Thus, the inclusion of up to $0.6 \%$ Capsicum ssp. (pepper) in balanced rations for ruminants does not alter the in vitro digestibility coefficient of dry matter, organic matter, crude protein, and neutral detergent fiber, or the in vitro fermentation parameters. However, the use of ruminal fluid as inoculum for the in vitro fermentation presented values of a higher degree of confidence in relation to feces to determine the in vitro digestion coefficient of the nutrients.

Key word: Ammoniacal nitrogen. Faeces. pH. Ruminal fluid.

\section{Resumo}

Avaliou-se a influência de pimenta (Capsicum ssp.) como aditivo alimentar em rações balanceadas para ovinos sobre os coeficientes de digestibilidade in vitro dos nutrientes e parâmetros de fermentação em dois inóculos diferentes: líquido ruminal e fezes de ovinos. Foram testados quatro teores de inclusão de pimenta $(0,0 \% ; 0,2 \% ; 0,4 \%$ e $0,6 \%$ da MS) e dois tipos de inóculos (líquido ruminal e fezes de ovinos) dispostos em arranjo fatorial $4 \times 2 \mathrm{em}$ um delineamento inteiramente casualizado. As rações experimentais foram balanceadas para apresentarem $0,0 \% ; 0,2 \% ; 0,4 \%$ e $0,6 \%$ de Capsicum ssp., com teor de $13,5 \%$ de proteína bruta e 70,0\% de nutrientes digestíveis totais (NDT). A ração fornecida aos animais doadores de inóculo foi de ração basal contendo $0,0 \%$ de Capsicum ssp, a qual foi utilizada $60 \%$ de volumoso (silagem de milho) e $40 \%$ de concentrado. Para a determinação dos coeficientes de digestibilidades in vitro (CDIV) dos nutrientes foram utilizados dois ovinos com peso corporal médio de 27,6 $\pm 1,6 \mathrm{~kg}$, como doadores de inóculos. As variáveis estudadas foram submetidas à análise de variância e para os teores de inclusão de pimenta procedeu-se análise de regressão a 5\% de probabilidade e para os diferentes inóculos foi realizado teste de Tukey a $5 \%$ de significância. A inclusão de $0,0 \%$; $0,2 \% ; 0,4 \%$ e $0,6 \%$ de pimenta (Capsicum ssp.) nas rações balanceadas dos ovinos não alteraram os $\mathrm{CDIV}$ da MS; MO; PB e FDN para ambos os inóculos (líquido ruminal e fezes de ovinos). Contudo, a utilização dos diferentes inóculos propiciou alteração no valor do CDIV da MS, MO, PB e FDN, no qual foi observado que o inóculo líquido ruminal apresentou maiores valores de $\mathrm{CD} I V$ em relação ao inóculo obtido das fezes de ovinos. Os teores de pimenta nas rações para ruminantes não alteraram o valor de $\mathrm{pH}$ do conteúdo fermentado após a incubação in vitro de 24 horas. Porém, a utilização do líquido ruminal como inóculo da fermentação in vitro das rações experimentais propiciou um menor valor para o pH do conteúdo fermentado em relação as fezes de ovinos. A inclusão de pimenta (Capsicum ssp.) nas rações de ovinos e a utilização de inóculo a base de líquido ruminal ou fezes de ovinos não propiciaram alterações na concentração do nitrogênio amoniacal $\left(\mathrm{N}^{-\mathrm{NH}_{3}}\right)$ do conteúdo fermentado das rações após incubação in vitro de 24 horas. Desta maneira, a inclusão de até $0,6 \%$ de pimenta em rações balanceadas para ruminantes não altera o coeficiente de digestibilidade in vitro da matéria seca, matéria orgânica, proteína bruta e fibra em detergente neutro e os parâmetros da fermentação in vitro. Contudo, a utilização do líquido ruminal como inóculo da fermentação in vitro apresenta valores com maior grau de confiança em relação as fezes para determinação do coeficiente de digestibilidade in vitro dos nutrientes.

Palavras-chave: Fezes. Inóculo. Nitrogênio amoniacal. pH. Líquido ruminal.

\section{Introduction}

Foods can be classified into various categories and groups; some foods may be part of more than one food group because of their numerous roles and diverse composition. The pepper of the genus Capsicum spp., of the functional food group, has tremendous potential to be used as a natural feed additive (REIFSCHNEIDER, 2000).
Functional foods are an elite group of nutrients. Besides containing nutrients, functional foods also have protective, medicinal, and therapeutic components with special curative actions, all of which make functional foods beneficial to human and animal health. Some examples of this group are garlic, onion, grape (juice and wine), lemon, acai, and peppers (BONTEMPO, 2007). 
Phytogenic additives may be defined as substances derived from or present in plants, generally comprising a wide variety of herbal spices and derived plant products such as essential oils, extracts, and oil-resins which may have a positive effect on production and yield in animal health (WINDISCH et al., 2008).

According to Araújo et al. (2007), consumers seek products of animal origin free of chemical residue and without additional cost. Thus, animal nutrition studies are increasingly focusing on strategies to improve the utilization of dietary nutrients, with the aim of establishing the optimal conditions for animal production (GERON et al., 2013).

Pepper presents itself as a natural alternative to the growth promoters used in animal production. Brazil is the second-largest pepper producer in the world (RISTORI et al., 2002; VALVERDE, 2011). The main botanical species of peppers cultivated in Brazil are identified by Brazilian researchers, following their popular names: chili (C. frutescens), finger of young, horned deer, cambuci and backcountry (C. baccatum), goat, smell and murici (C. chinense), bird and cumari (C. praetermissum), $\mathrm{cv}$. Agronomic 11 (C. annuum) (FILGUEIRA, 2000).

Peppers have diverse chemical compositions, with the main components being capsaicinoids, carotenoids and ascorbic acid, which may vary according to genotype and degree of maturation (DUTRA et al., 2010). Capsaicin, composed of 8-methyl-N-vanylyl-6-nonenamide, is a phenolic alkaloid, lipophilic in character and found in red peppers (Capsicum ssp.), Also known as capsaicinoid (IWAI et al., 2003; SILVA, 2017), it has proven medicinal properties, acting as a healing, antioxidant, and bactericidal agent, which aids in the dissolution of blood clots, prevents arteriosclerosis, controls cholesterol, prevents bleeding, increases caloric expenditure, and influences the release of endorphins (DUTRA et al., 2010).
Capsaicinoid concentrations in pepper species may vary. Thus, the mildly "spicy" pepper varieties contain capsaicinoid concentrations ranging from $0.003 \%$ to $0.01 \%$ dry weight of raw material. Less spicy peppers contain concentrations of capsaicinoids between $0.01 \%$ and $0.3 \%$, and strongly spicy varieties are characterized by a content greater than $0.3 \%$ may reach up to $1 \%$ of total dry weight of capsaicinoids (PERUCKA; OLESZEK, 2000; HAYMAN; KAM, 2008; AGUIAR et al., 2014; SANTOS et al., 2015). Thus, the literature indication is that Capsicum peppers have a mean capsaicinoid content of $0.5 \%$, with capsaicin being the major capsaicinoid.

The antimicrobial activity of capsaicin is due to the phenolic compound in its chemical composition (MANAIA, 2011). Capsaicin has a high rate of intestinal absorption (SURESH; SRINIVASAN, 2010). In addition, capsaicinoids receptors are found in the oral cavity, i.e. they can be activated without passing through the digestive tract (INOUE et al., 2007; LUDY et al., 2012). A pepper extract containing capsaicin was reported to reduce ruminal action by Cardozo et al. (2004). However, Calsamiglia et al. (2007) reported that the active ingredient of pepper reduced bacterial activity in in vitro fermentation of diets rich in forage, but for diets with a higher concentrate ratio there may be an increase in short-chain fatty acids (SCFAs) and reduction of ammoniacal $\mathrm{N}$. Thus, further research should be conducted to observe the digestive behavior and performance of ruminant animals using phytogenic plants in an in vivo study.

Thus, it is important to evaluate the inclusion of pepper (functional food) as a food additive (Capsicum ssp.) in balanced diets for sheep. Given the above, the objective of the study was to evaluate the inclusion of different levels of pepper (Capsicum ssp.): $0.0 \% ; 0.2 \% ; 0.4 \%$ and $0.6 \%$ on in vitro digestibility and parameters of in vitro fermentation in sheep diets with two types of inoculum: ruminal fluid and sheep feces. 


\section{Material and Methods}

The experiment was carried out at the Animal Metabolism Sector and at the Animal Food and Nutrition Analysis Laboratory, belonging to the Pontes and Lacerda University Campus of the State University of Mato Grosso - UNEMAT. This study was filed under number 001/2017 and approved by the Animal Use Ethics Commission - CEUA / UNEMAT.

The feeds used in the experimental diets were corn silage, ground corn grain and soybean meal, and a pool of dehydrated pepper, which contained equal parts in the dry matter of four pepper species: Capsicum frutescens; C. Baccatu; C. chinense and C. annum.

Capsicum peppers were collected from both commercial and non-commercial plantations in the municipality of Pontes e Lacerda, of the southwest region of Mato Grosso State, from January to May 2017.
The different species of Capsicum were processed through a $10 \mathrm{~mm}$ sieve crusher and then placed to dry in the sun in a $3 \mathrm{~cm}$ high layer on an individual plastic tarp, for approximately $96 \mathrm{~h}$. After drying, the mixture of equal proportions of the four species of Capsicum ssp. was used as a phytogenic additive for the study.

The in vitro digestion diets were prepared using the combination of four pepper inclusion contents $(0.0 \%, 0.2 \%, 0.4 \%$, and $0.6 \%)$ in the dry matter of formulated sheep diets and two inoculum types used in fermentation (ruminal fluid and sheep feces), in a $4 \times 2$ factorial arrangement in a completely randomized design.

The experimental foods are shown in Table 1 and the experimental rations were balanced to present $0.0 \% ; 0.2 \% ; 0.4 \%$ and $0.6 \%$ Capsicum ssp. (Table 2) with $13.5 \%$ crude protein content and $70.0 \%$ total digestible nutrients according to NRC (2007), to induce a moderate gain of 80 to $130 \mathrm{~g} \mathrm{animal}^{-1}$ day ${ }^{1}$. The feed provided to the inoculum donor animals was a basal feed of $60 \%$ roughage (corn silage) and $40 \%$ concentrate containing $0.0 \%$ Capsicum ssp.

Table 1. Bromatological composition of experimental foods.

\begin{tabular}{ccccccccccc}
\hline \multirow{2}{*}{ Foods } & \multicolumn{10}{c}{ nutrients expressed g kg ${ }^{-1}$ in DM } \\
\cline { 2 - 11 } & DM & OM & CP & EE & NDF & ADF & TC & NFC & TND $^{1}$ & $\begin{array}{c}\text { Capsaicin } \\
\text { mg g-1 DM }^{*}\end{array}$ \\
\hline CS & 318.6 & 968.0 & 89.6 & 29.1 & 672.9 & 351.6 & 849.3 & 176.4 & 601.0 & - \\
GC & 900.8 & 939.1 & 86.9 & 27.9 & 172.2 & 68.6 & 814.2 & 642.0 & 860.3 & - \\
SM & 913.1 & 980.5 & 492.6 & 25.5 & 129.7 & 85.9 & 462.4 & 332.7 & 807.3 & - \\
Capsicum ssp. -pepper & 256.7 & 949.2 & 178.2 & 46.8 & 339.7 & 160.3 & 724.2 & 389.0 & 759.0 & 0.50 \\
\hline
\end{tabular}

CS: corn silage; CG: ground corn; SM: soybean meal; DM: dry matter; OM: organic matter; CP: crude protein; EE: ether extract; NDF: neutral detergent fiber; ADF: acid detergent fiber; TC: total carbohydrates; NFC: non-fibrous carbohydrates and TDN: total digestible nutrients. * (PERUCKA; OLESZEK, 2000; HAYMAN; KAM, 2008; AGUIAR et al., 2014; SANTOS et al., 2015). ${ }^{1}$ Estimated energy value of the literature average (VALADARES FILHO et al., 2010; TABNUT, 2006).

Two crossbred sheep, kept in a metabolism cage, with an average body weight of $27+1.6 \mathrm{~kg}$, were used as inoculum donors. The sheep were allowed to adapt to the experimental conditions for 15 days, and 15 days before the start of the experiment the sheep were dewormed with the ivermectin product.

Basal feed intake of the sheep was controlled so that there was $10 \%$ leftover after each meal and provided in two daily portions at 7 am and $5 \mathrm{pm}$, 
respectively. Sheep were given free access to water through individual drinking fountains. In addition, 5 g per animal of a mineral mixture was provided per meal, which was added directly to the experimental concentrates.

On the day of inoculum collection (ruminal fluid), the sheep were fed at 7 o'clock, and after two hours, the ruminal fluid was collected according to Zeoula et al. (2003). Approximately $0.6 \mathrm{~L}$ of ruminal fluid was collected from each animal to form a composite mixture. The ruminal fluid was filtered through a cotton filter after collection and placed in a thermos containing $\mathrm{CO}_{2}$. $0.5 \mathrm{~L}$ filtered ruminal fluid was used as the inoculum in the in vitro incubation process of diets containing Capsicum ssp.

Table 2. Percentage and bromatological composition of experimental diets containing pepper (Capsicum ssp.).

\begin{tabular}{|c|c|c|c|c|}
\hline \multirow[t]{2}{*}{ Foods } & \multicolumn{4}{|c|}{ Levels of pepper in the experimental diets $\left(\mathrm{g} \mathrm{kg}^{-1}\right)$} \\
\hline & $0.0 \%$ & $0.2 \%$ & $0.4 \%$ & $0.6 \%$ \\
\hline Corn silage & 600.00 & 600.00 & 600.00 & 600.00 \\
\hline Ground corn & 265.00 & 263.00 & 261.00 & 259.00 \\
\hline Soybean meal & 135.00 & 135.00 & 135.00 & 135.00 \\
\hline Capsicum ssp. (pepper) & 0.00 & 2.00 & 4.00 & 6.00 \\
\hline Total (g) & $1,000.00$ & $1,000.00$ & $1,000.00$ & $1,000.00$ \\
\hline \multicolumn{5}{|c|}{ Bromatological composition of experimental diets $\left(\mathrm{g} \mathrm{kg}^{-1}\right.$ in DM) } \\
\hline ADS Dry Matter & 916.10 & 914.80 & 913.50 & 912.20 \\
\hline Organic matter & 962.00 & 962.00 & 962.00 & 962.10 \\
\hline Crude protein & 143.30 & 143.50 & 143.70 & 143.80 \\
\hline Ether extract & 30.90 & 31.00 & 31.00 & 31.00 \\
\hline Neutral detergent fiber & 466.90 & 467.20 & 467.50 & 467.90 \\
\hline Acid detergent fiber & 243.40 & 243.60 & 243.80 & 244.00 \\
\hline Total carbohydrates & 787.80 & 787.60 & 787.40 & 787.20 \\
\hline Non-fibrous carbohydrates & 320.90 & 320.40 & 319.90 & 319.40 \\
\hline Capsaicin $\mathrm{mg} \mathrm{g}^{-1}$ de DM of pepper & 0.00 & 2.60 & 5.10 & 7.70 \\
\hline Total digestible nutrients & 697.60 & 697.40 & 697.20 & 697.00 \\
\hline
\end{tabular}

The collection of feces (inoculum) was taken directly from the rectum of the inoculum donor sheep at a ratio of 1: 1 of buffer: feces, which is 200: 200, according to the recommendation of Alcalde et al. (2001). Stool collection was performed 30 minutes prior to ruminal fluid collection, as feces were accumulating in the rectum of the animals.

For the assay of in vitro digestion of nutrients, four field replications were performed in fermentation batteries; each battery consisted of three tubes of the experimental ration with each of $0.0 \% ; 0.2 \% ; 0.4 \%$ and $0.6 \%$ Capsicum ssp. incubated with two types of inoculum (ruminal fluid and sheep feces) and three white tubes per battery for the development of the in vitro digestibility method, according to the onestage technique adapted from Smith et al. (2010), for a period of 24 hours of in vitro fermentation.

Artificial saliva was used for the in vitro digestibility assay, which was initially prepared with McDougall's buffer solution $\left(\mathrm{NaHCO}_{3}, \mathrm{Na}_{2} \mathrm{HPO}_{4}\right.$ $7 \mathrm{H}_{2} \mathrm{O}, \mathrm{KCl}, \mathrm{NaCl}, \mathrm{MgSO}_{4} 7 \mathrm{H}_{2} \mathrm{O}, \mathrm{CaCl}_{2}$ ) and two more solutions, one of urea $\left(5.5 \mathrm{~g} 100 \mathrm{~mL}^{-1}\right.$ distilled 


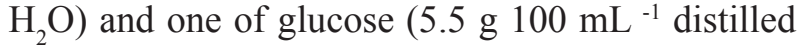
$\mathrm{H}_{2} \mathrm{O}$ ). On the day before the in vitro incubation, $5 \mathrm{~mL}$ of the urea buffer solution and $5 \mathrm{~mL}$ of the glucose buffer solution were added to each $300 \mathrm{~mL}$ of McDougall's solution and kept in an oven at 39 ${ }^{\circ} \mathrm{C}$ until use.

The $\mathrm{pH}$ value of artificial saliva was measured and was stabilized close to 6.8 to 7.0 with the addition of $\mathrm{CO}_{2}$. The tubes were prepared with $0.5 \mathrm{~g}$ of the experimental diets containing $0.0 \%$; $0.2 \% ; 0.4 \%$ and $0.6 \%$ Capsicum ssp., and 37.5 $\mathrm{mL}$ of McDougall artificial saliva solution (MCDOUGALL, 1948) was added to each tube at the time of incubation with $12.5 \mathrm{~mL}$ of inoculum (ruminal fluid) or (sheep feces) according to Smith et al. (2010). The tubes were then filled with $\mathrm{CO}_{2}$ and immediately sealed with rubber stoppers fitted with a Bünsen valve (GERON et al., 2017).

After this procedure, the tubes were placed in a Dubnoff type water bath (microprocessor digital, with an automatic heater, mod. Q226 M1 Quimis $\left.{ }^{\circledR}\right)$, with water at a temperature of $39.2^{\circ} \mathrm{C}$ and constantly agitated for 24 hours.

After the 24 hours of incubation, fermentation was stopped by placing the tubes in a container of crushed ice for 10 minutes. The contents of the tubes were filtered on a quantitative filter paper (black band, diameter $15 \mathrm{~cm}$ for rapid filtration for thick and gelatinous precipitates), and the in vitro fermented content retained in the filters was placed in an oven at $65^{\circ} \mathrm{C}$, for 72 hours. The filters were then placed in a desiccator for subsequent weighing. The $\mathrm{pH}$ value of the remaining filtration liquid was measured and $0.2 \mathrm{ml}$ of $1: 1$ sulfuric acid was added per aliquot $(20 \mathrm{~mL})$ of the fermented content after filtration to acidify the medium and consequently stop fermentation, these samples were used to determine the ammoniacal nitrogen $\left(\mathrm{NH}_{3}-\mathrm{N}\right)$ concentration of the fermentation content after 24 hours of in vitro incubation (GERON et al., 2017).

$\mathrm{NH}_{3}-\mathrm{N}$ concentrations in the samples of the filtered fermented content were determined by distillation with potassium hydroxide $\mathrm{KOH} 2 \mathrm{~mol}$ $\mathrm{L}^{-1}$, according to the technique described by Preston (1995).

The in vitro digestibility coefficient (IVDC) of dry matter (DM) and other nutritive components of the diets with the different inclusion levels of Capsicum ssp. was determined by the formula: DM $I V \mathrm{DC}=$ sample weight $(\mathrm{g} \mathrm{DM})$ - [residue weight (g DM) - white weight (g DM)]./ sample weight (g DM) X 100 proposed by Silva and Queiroz (2002).

Bulk feed samples (corn silage) were oven-dried at $55 \pm 5^{\circ} \mathrm{C}$ for 72 hours, after which time they were processed in a knife mill and sieved through a $1 \mathrm{~mm}$ diameter sieve.

The nitrogen content of the samples of the experimental foods was determined by the semimicro Kjeldahl method, mineral matter (MM), organic matter $(\mathrm{OM})$ and ether extract $(\mathrm{EE})$ were determined according to quotes by Silva and Queiroz (2002), and neutral detergent fiber as recommended by Van Soest et al. (1991), without the use of sulfite and without correcting the NDF and ADF values in relation to the mineral matter content of the fiber.

The studied variables, in vitro digestibility coefficient (IVDC) of nutrients, $\mathrm{pH}$ value and $\mathrm{NH}_{3}-\mathrm{N}$ concentration of fermented content after 24 hours of incubation for rations with $0.0 \% ; 0.2 \%$; $0.4 \%$ and $0.6 \%$ Capsicum ssp. were submitted to analysis of variance by SAEG software (UFV, 1997), considering a probability of 0.05 . When significance was verified for the different inocula (ruminal fluid of sheep feces), which was used for the determination of nutrient $I V D C$ from the experimental diets, a Tukey test was performed at $5 \%$ of significance. For the different inclusion levels of Capsicum ssp., a regression analysis at 5\% of significance was performed.

\section{Results and Discussion}

The contents of $0,0 \% ; 0.2 \% ; 0.4 \%$ and $0.6 \%$ inclusion of pepper in the balanced diets for sheep 
did not influence $(\mathrm{P}>0.05)$ the in vitro digestibility coefficients (IVDC) of DM; OM; CP and NDF for both inocula, rumen fluid and sheep feces (Table 3). However, there was an influence of inoculum on the mean values of IVDC of DM; OM; CP and NDF, which were $68.41 \mathrm{~g} \mathrm{~kg}^{-1}$ and $62.58 \mathrm{~g} \mathrm{~kg}^{-1} ; 71.52 \mathrm{~g}$ $\mathrm{kg}^{-1}$ and $65.77 \mathrm{~g} \mathrm{~kg}^{-1} ; 60.55 \mathrm{~g} \mathrm{~kg}^{-1}$ and $61.23 .03 \mathrm{~g}$ $\mathrm{kg}^{-1}$, and $60.61 \mathrm{~g} \mathrm{~kg}^{-1}$ and $49.82 \mathrm{~g} \mathrm{~kg}^{-1}$, respectively (P $<0.05$; Table 3).

Table 3. In vitro digestibility (IVDC) of dry matter and nutrients using as liquid inoculum rumen and feces in sheep to sheep balanced feed containing different levels of pepper.

\begin{tabular}{|c|c|c|c|c|c|c|c|}
\hline \multirow{2}{*}{ Item } & \multirow{2}{*}{ Inoculum } & \multicolumn{4}{|c|}{ Levels of pepper in the experimental diets } & \multirow{2}{*}{ Regression } & \multirow{2}{*}{$\% \mathrm{CV}$} \\
\hline & & $0.0 \%$ & $0.2 \%$ & $0.4 \%$ & $0.6 \%$ & & \\
\hline \multicolumn{8}{|c|}{ Variables expressed in $\mathrm{g} \mathrm{kg}^{-1}$} \\
\hline$I V \mathrm{DC} \mathrm{DM}$ & Rum. Liq. & 679.10 & 706.40 & 694.70 & 656.10 & $\mathrm{Y}=684.10 \mathrm{~b}$ & 8.74 \\
\hline$I V \mathrm{DC} \mathrm{DM}$ & Feces & 601.30 & 647.20 & 627.60 & 629.60 & $\mathrm{Y}=625.80 \mathrm{a}$ & 9.75 \\
\hline$I V \mathrm{DC} \mathrm{OM}$ & Rum. Liq. & 715.60 & 741.20 & 706.90 & 696.90 & $\mathrm{Y}=715.20 \mathrm{~b}$ & 11.48 \\
\hline$I V \mathrm{DC} \mathrm{OM}$ & Feces & 650.20 & 667.10 & 663.70 & 650.00 & $\mathrm{Y}=657.70 \mathrm{a}$ & 10.75 \\
\hline$I V \mathrm{DC} C \mathrm{P}$ & Rum. Liq. & 588.20 & 632.40 & 604.90 & 596.60 & $\mathrm{Y}=605.50 \mathrm{a}$ & 11.86 \\
\hline$I V \mathrm{DC} C \mathrm{P}$ & Feces & 626.10 & 632.10 & 601.40 & 589.70 & $\mathrm{Y}=612.30 \mathrm{a}$ & 13.49 \\
\hline$I V D C$ NDF & Rum. Liq. & 595.30 & 628.80 & 616.60 & 583.60 & $\mathrm{Y}=606.10 \mathrm{~b}$ & 8.46 \\
\hline IVDC NDF & Feces & 498.20 & 515.20 & 492.90 & 486.40 & $\mathrm{Y}=498 ., 20 \mathrm{a}$ & 8.80 \\
\hline
\end{tabular}

Rum. Liq.: ruminal liquid - inoculum. CV: coefficient of variation; DM: dry matter; OM: organic matter; CP: crude protein and NDF: neutral detergent fiber. Averages in the same column and variable followed by the same lowercase letter do not differ by the $5 \%$ Tukey test.

Inclusion of $0.6 \%$ Capsicum ssp. in the experimental diets provided a capsaicin content of $0.077 \mathrm{mg} 100^{-1} \mathrm{~g}$ of pepper (Table 2), this level of phenolic (capsaicinoid) compounds was probably not sufficient to change the activity of the microflora from the inoculum from ruminal fluid or sheep feces. Moreover, the expected positive associative effect of the mixture of the different ingredients in the experimental diets did not elicit the expected microbial activity, this fact may have been influenced by the 60:40 forage: concentrate ratio.

Similarly, a study conducted by Cardozo et al. (2004), to evaluate the inclusion of capsaicincontaining pepper essential oil on an in vitro culture of ruminal fluid from dairy cattle fed $60 \%$ alfalfa hay and $40 \%$ concentrate, indicated that capsaicin had a negligible effect on the in vitro fermentation process.

The constant IVDC response of nutrients from experimental diets fermented with Capsicum ssp. may be associated with the low number of oxygen molecules in capsaicin, which are directly related to the antimicrobial activity of terpenes (GRIFFIN et al., 1999; DORMAN; DEANS, 2000), however, an effect on IVDC was expected due to the synergism of the various compounds present in pepper, which possibly act on different carbohydrate and proteinfermenting bacteria during in vitro fermentation.

However, an in vitro study using Capsicum oil in the contents of $0,0.3,3,30$ and $300 \mathrm{mg} \mathrm{L}^{-1}$ and the use 
of bovine ruminal fluid inoculum was conducted by Cardozo et al. (2005). These authors fed the cattle a diet containing $10 \%$ straw and $90 \%$ concentrate and observed that the concentrations of volatile fatty acids (VFAs) and ammonia $\left(\mathrm{NH}_{3}\right)$ were reduced and that the acetate: propionate ratio was increased in an environment with a $\mathrm{pH}$ value of 7.0 (neutral). However, at pH 5.5 (acidic), Capsicum oil reduced the concentration of $\mathrm{NH}_{3}$ and increased the total production of VFAs. Thus, these authors suggested that the use of Capsicum oil in high-concentrate cow diets may improve the use of rumen nutrients, as a low pH may change the capsaicin molecule to a more hydrophobic status, which would make it more effective as an antimicrobial.

Cardozo et al. (2006) used Capsicum oil (1 $\mathrm{g} \mathrm{A}^{-1}$ day $^{-1}$ containing $15 \%$ capsaicin) to feed cannulated beef cattle fed $90 \%$ concentrate and $10 \%$ roughage. These authors observed that the use of Capsicum oil in cattle did not change the concentration of SCFAs, but that there was a molar reduction of acetate in the rumen. Moreover, this addition reduced peptides and increased amino acids (AA) but had no effect on ammonia. The authors suggested that capsaicin stimulated peptidolysis, which may provide more peptides and AA for the synthesis of ruminal bacteria.

It was observed that the $I V \mathrm{DC}$ levels of $\mathrm{DM}, \mathrm{OM}$, and NDF of the experimental diets containing the different levels of Capsicum ssp. was lower $(\mathrm{P}<0.05)$ for the in vitro fermentation method with sheep feces inoculum in relation to the ruminal liquid use (Table 3). These results demonstrated that the use of sheep feces as inoculum caused an underestimation of the determined in vitro digestibility coefficient of DM, OM, and NDF. However, a study by Geron et al. (2019), to evaluate the inclusion of Noni (Morinda citrofolia) in ruminant feed in an in vitro study, demonstrated that the use of feces could replace ruminal fluid without altering the IVDC of DM, OM, and CP. The use of the phytogenic additive Capsicum ssp., in the present study, may have exerted greater selection pressure on bacteria present in sheep feces in relation to the rumen fluid.

However, no significant difference was observed for $I V \mathrm{DC}$ of $\mathrm{CP}$ from the experimental diets for both inocula: (ruminal fluid and sheep feces), (Table 3). The average value of CP IVDC for diets containing Capsicum ssp. for in $0.0 \%$ ass, liquid rumen was $60.55 \mathrm{~g} \mathrm{~kg}^{-1}$ and for the sheep stool inoculum $61.23 \mathrm{~g} \mathrm{~kg}^{-1}$. Possibly, the characteristic suggested by Cardozo et al. (2006), which indicates that capsaicin present in pepper oil has a peptide lysis effect, thereby increasing the concentration of $\mathrm{AA}$ and a detrimental reduction of peptides without affecting the concentration of ammonia, the use of both inoculants may have contributed to this effect in the fermentation process, in vitro, therefore, for both inocula there was a similar hydrolysis of the dietary protein.

The contents of $0,0 \% ; 0.2 \% ; 0.4 \%$ and $0.6 \%$ Capsicum ssp. in ruminant feeds did not $(\mathrm{P}>0.05)$ influence the $\mathrm{pH}$ of the fermented content after 24-hours in vitro incubation for both inocula (Table 4). The mean $\mathrm{pH}$ values of the fermented content of the experimental diets after 24 hours of in vitro fermentation were 7.70 and 7.94 for ruminal fluid inoculum and sheep feces, respectively. These results indicate that regardless of the inclusion content of Capsicum ssp. in in vitro fermented sheep diets provided values above 7.0 for the $\mathrm{pH}$ of the fermented content after 24 hours of fermentation, this fact reinforces that regardless of the inclusion content of Capsicum ssp. There was no change in substrate fermentation in the diets. 
Table 4. Ammonia nitrogen and $\mathrm{pH}\left(\mathrm{NH}_{3}-\mathrm{N} \mathrm{mg} 100 \mathrm{~mL}^{-1}\right)$ content of fermented content after 24 hours of in vitro incubation of diets containing pepper in sheep

\begin{tabular}{|c|c|c|c|c|c|c|c|}
\hline \multirow{2}{*}{ Variable } & \multirow{2}{*}{ Inoculum } & \multicolumn{4}{|c|}{ Inclusion of Capsicum ssp in experimental diets } & \multirow{2}{*}{ Regression } & \multirow{2}{*}{$\% \mathrm{CV}$} \\
\hline & & $0,0 \%$ & $0,2 \%$ & $0,4 \%$ & $0,6 \%$ & & \\
\hline $\mathrm{pH}$ & Rum. Liq. & 7.63 & 7.67 & 7.78 & 7.72 & $\mathrm{Y}=7.70 \mathrm{a}$ & 2.10 \\
\hline $\mathrm{pH}$ & Feces & 7.80 & 8.08 & 7.96 & 7.92 & $\mathrm{Y}=7.94 \mathrm{~b}$ & 2.50 \\
\hline $\mathrm{NH}_{3}-\mathrm{N}$ mg $100 \mathrm{~mL}^{-1}$ & Rum. Liq. & 47.25 & 49.00 & 53.38 & 51.45 & $\mathrm{Y}=50.27 \mathrm{a}$ & 30.88 \\
\hline $\mathrm{NH}_{3}-\mathrm{N}$ mg $100 \mathrm{~mL}^{-1}$ & Feces & 50.93 & 54.60 & 51.28 & 49.53 & $Y=51.59 a$ & 27.90 \\
\hline
\end{tabular}

Rum. Liq.: ruminal liquid - inoculum, CV: coefficient of variation. Means in the same column and variable followed by the same lowercase letter do not differ by the $5 \%$ Tukey test.

However, it was observed that the use of ruminal fluid as in vitro fermentation inoculum provided a lower $\mathrm{pH}$ value $(\mathrm{P}<0.05)$ for the experimental diets in relation to the inoculum of sheep feces (Table 4). This suggests that the feces of sheep have a certain limitation as inoculum in the in vitro study of food digestibility.

However, in a study by Geron et al. (2019), to evaluate the use of Noni inclusion in ruminant feeds by the in vitro fermentation process using rumen liquid inoculum and sheep feces, the authors did not observe any difference in the $\mathrm{pH}$ value of the fermented content after 24 hours of fermentation. This study indicated the use of alternative feces to replace rumen fluid in the in vitro fermentation process of basal diets containing Noni inclusion.

The inclusion of $0.0 \%, 0.2 \% ; 0.4 \%$ and $0.6 \%$ Capsicum spp. in ruminant rations for both inocula the liquid-based rumen or sheep feces did not lead to changes $(\mathrm{P}>0.05)$ in the concentration of ammonia nitrogen $\left(\mathrm{NH}_{3}-\mathrm{N}\right)$ of the fermented feed content after 24 hours of in vitro incubation (Table 4 ).

The use of different inocula, namely ruminal fluid or sheep feces, in the in vitro fermentation process of diets containing phytogenic additive Capsicum ssp. did not change $(\mathrm{P}<0.05)$ the $\mathrm{NH}_{3}-\mathrm{N}$ concentration of the fermented content, with mean values of 50.27 $\mathrm{mg} \mathrm{NH}_{3}-\mathrm{N} 100 \mathrm{~mL}^{-1}$ for ruminal fluid inoculum and

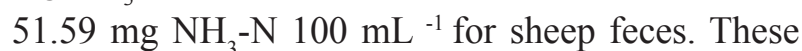
results showing $\mathrm{NH}_{3}-\mathrm{N}$ concentrations higher than $20 \mathrm{mg} 100 \mathrm{~mL}^{-1}$ corroborate the values obtained for the fermented content with a $\mathrm{pH}$ above 7.0 for both inocula (Table 4).

In general, in the in vivo studies on ruminal parameters, a lower $\mathrm{pH}$ value of the ruminal fluid is observed compared to that in the in vitro study for the $\mathrm{pH}$ of the fermented content; this may be due to the absorption dynamics of volatile fatty acids and ammonia nitrogen in the rumen (GERON et al., 2017) in relation to the system in vitro, and due to the fact that excited ions are dependent on the consumer's will, as this may change the retention time of food in the gastrointestinal tract, which does not occur with "in vitro" studies.

\section{Conclusions}

The inclusion in balanced sheep diets of up to $0.6 \%$ pepper dry matter content does not change the in vitro digestibility coefficient of dry matter, organic matter, crude protein, and neutral detergent fiber or the in vitro fermentation parameters.

However, the use of ruminal fluid as inoculum for in vitro fermentation presents greater confidence values in relation to inoculum from sheep feces.

\section{Thanks}

We are grateful to the Mato Grosso State Research Support Foundation (FAPEMAT) for funding the present study. 


\section{References}

AGUIAR, A. C.; SANTOS, P.; COUTINHO, J. P.; BARBERO, G. F.; GODOY, H. T.; MARTINEZ, J. Supercritical fluid extraction and low pressure extraction of biquinho pepper (Capsicum chinense). LWT - Food Science and Technology, London, v. 59, n. 2, p. 1239246, 2014. DOI: 10.1016/j.lwt.2014.06.014

ALCALDE, C. R.; MACHADO, R. M.; SANTOS, G. T.; PICOLLI, R.; JOBIM, C. C. Digestibilidade in vitro de alimentos com inóculos de líquido de rúmen ou de fezes de bovinos. Acta Scientiarum. Animal Science, Maringá, v. 24, n. 4, p. 917-921, 2001. DOI: 10.4025/ actascianimsci.v23i0.2645

ARAÚJO, J. A.; SILVA, J. H. V.; AMÂNCIO, A. L. L.; LIMA, M. R.; LIMA, C. B. Uso de aditivos na alimentação de aves. Acta Veterinaria Brasílica, Mossoró, v. 1, n. 3, p. 69-77, 2007. DOI: 10.21708/avb.2007.1.3.488

BONTEMPO, M. Pimenta e seus beneficios à saúde. São Paulo: Editora Alaúde, 2007. 150 p.

CALSAMIGLIA, S.; BUSQUET, M.; CARDOZO, P. W.; CASTILlEJOS, L.; FERRET, A. Invited review: essential oils as modifiers of rumen microbial fermentation. Journal of Dairy Science, Champaign, v. 90 , n. 6, p. $2580-2595$, 2007. DOI: $10.3168 /$ jds.2006-644

CARDOZO, P. W.; CALSAMIGLIA, S.; FERRET, A.; KAMEL, C. Effects of alfalfa extract, anise, capsicum and a mixture of cinnamaldehyde and eugenol on ruminal fermentation and protein degradation in beef heifers fed a high concentrate diet. Journal of Animal Science, Champaign, v. 84, n. 1, p. 2801-2808, 2006. DOI: $10.2527 /$ jas.2005-593

CARDOZO, P. W.; CALSAMIGLIA, S.; FERRET, A.; KAMEL, C. Effects of natural plant extracts on ruminal protein degradation and fermentation profiles in continuous culture. Journal of Animal Science, Champaign, v. 82 , n. 11 , p. $3230-3236,2004$. DOI: $10.2527 / 2004.82113230 \mathrm{x}$

CARDOZO, P. W.; CALSAMIGLIA, S.; FERRET, A.; KAMEL, C. Screening for the effects of natural plant extracts at different $\mathrm{pH}$ on in vitro rumen microbial fermentation of high-concentrate diet for beef cattle. Journal of Animal Science, Champaign, v. 83, n. 11, p. 2572-2579, 2005. DOI: $10.2527 / 2005.83112572 x$

DORMAN, H. J. D.; DEANS, S. G. Antimicrobial agents from plants: antibacterial activity of plant volatile oils. Journal Applied Microbiology, Athens, v. 88, n. 2, p. 308-316, 2000. DOI: 10.1046/j.1365-2672.2000.00969.x

DUTRA, F. L. A.; BRANCO, I. G; MADRONA, G. S.; HAMINIUK, C. W. I. Avaliação sensorial e influência do tratamento térmico no teor de ácido ascórbico de sorvete de pimenta. Revista Brasileira de Tecnologia Agroindustrial, Curitiba, v. 4, n. 2, p. 243-251, 2010. DOI: $10.3895 / \mathrm{S} 1981-368620100002000012$

FILGUEIRA, F. A. R. Novo manual de olericultura: agrotecnologia moderna na produção e comercialização de hortaliças. Viçosa, MG: UFV, 2000. 402 p.

GERON, L. J. V.; GARCIA, J.; COELHO, K. S. M.; AGUIAR, S. C.; ZANINE, A. M.; SOUZA, A. L.; CARVALHO, J. T. H.; ROBERTO, L. S.; SOUSA NETO, E. L.; FERREIRA, D. J. In vitro digestibility and nutritional characterization of distillers dried grains with solubles according to the Cornell Net Carbohydrate and Protein System. Semina: Ciências Agrárias, Londrina, v. 38, n. 4, p. 2029-2040, 2017. DOI: $10.5433 / 1679-0359.2017 \mathrm{v} 38 \mathrm{n} 4 \mathrm{p} 2029$

GERON, L. J. V.; MEXIA, A. A.; CRISTO, R. L.; GARCIA, J.; CABRAL, L. S.; TRAUTAMANN, R. J.; MARTINS, O. S.; ZEOULA; L. M. Consumo, digestibilidade dos nutrientes e características ruminais de cordeiros alimentados com níveis crescentes de concentrado em ambiente tropical no Vale do Alto Guaporé - MT. Semina: Ciências Agrárias, Londrina, v. 34, n. 5, p. $2497-2510,2013$. DOI: $10.5433 / 1679-0359.2013 v 34$ n5p2497

GERON, L. J. V.; VELOSO, L. E. C.; AGUIAR, S. C.; SOUZA, A. L.; SOUZA, I. S.; TRAUTAMNMACADO, R. J.; ZANINE, A. M.; SILVA, R. F.; FERREIRA, D. J.; ZANIN, S. F. P. In vitro fermentation of the rations containing Morinda citrifolia L. (Noni) using two types of inoculum. Semina: Ciências Agrárias, Londrina, v. 40, n. 2, p. 831-842, 2019. DOI: $10.5433 / 1679-0359.2019 \mathrm{v} 40 \mathrm{n} 2 \mathrm{p} 831$

GRIFFIN, S. G.; WYLLIE, S. G.; MARKHAM, J. L.; LEACH, D. N. The role of structure and molecular properties of terpenoids in determining their antimicrobial activity. Flavour and Fragrance Journal, Paris, v. 14, n. 2, p. 322-332, 1999. DOI: 10.1002/(SICI)10991026(199909/10)14:5<322::AID-FFJ837>3.0.CO;2-4

HAYMAN, M.; KAM, P. C. A. Capsaicin: a review of its pharmacology and clinical applications. Current Anaesthesia \& Critical Care. Valencia, v. 19, n. 5, p. 338343, 2008. DOI: 10.1016/j.cacc.2008.07.003

INOUE, N.; MATSUNAGA, Y.; SATOH, H.; TAKAHASHI, M. Enhanced energy expenditure and fat oxidation in humans with high bmi scores by the ingestion of novel and non-pungent capsaicin analogues (Capsinoids). Bioscience, Biotechnology and Biochemistry, Tokyo, v. 71, n. 2, p. 380-389, 2007. DOI: 10.1271/bbb.60341

IWAI, B. K.; YAZAWA, A.; WATANABE, T. Roles as metabolic regulators of the non-nutrients, capsaicin and capsiate, supplemented to diets. Proceedings of the 
Japan Academy, Tokyo, v. 79, n. 7, p. 207-212, 2003. DOI: $10.2183 /$ pjab.79B.207

LUDY, M. J.; MOORE, G. E.; MATTES, R. D. The effects of capsaicin and capsiate on energy balance: critical review and meta-analyses of studies in humans. Chemical Senses, Oxford, v. 37, n. 2, p. 103-121, 2012. DOI: $10.1093 /$ chemse/bjr100

MANAIA, M. A. N. Mecanismos redox relativos à actividade antioxidante de sistemas fenólicos. 2011. Dissertação (Mestrado em Engenharia de Alimentos) Universidade de Coimbra, Coimbra.

MCDOUGALL, E. I. Studies on ruminant saliva. 1- The composition and output of sheep's saliva. Biochemistry Journal, Nashville, v. 43, n. 1, p. 99-109, 1948. DOI: PMC1274641

NATIONAL RESEARCH COUNCIL - NRC. Nutrient requirements of small ruminants: sheep, goats, cervids, and new world camelids. Washington: National Academy Press, 2007. 384 p.

PERUCKA, I.; OLESZEK, W. Extraction and determination of capsaicinoids in fruit of hot pepper Capsicum annuum L. by spectrophotometry and highperformance liquid chromatography. Food Chemistry, London, v. 71, n. 2, p. 287-291, 2000. DOI: 10.1016/ S0308-8146(00)00153-9

PRESTON, T. R. Biological and chemical analytical methods. In: PRESTON, T. R. Tropical animal feeding: a manual for research workers. Rome: FAO, 1995. p. 191264.

REIFSCHNEIDER, F. J. B. Capsicum: pimentas e pimentões no Brasil. Brasília: Embrapa Comunicação para Transferência de Tecnologia, Embrapa Hortaliças, Brasília, DF, 2000. 114 p.

RISTORI, C. A.; PEREIRA, M. A. dos S.; GELLI, D. S. $O$ efeito da pimenta do reino moída frente a contaminação in vitro com Salminella Rubslaw. Revista do Instituto Adolfo Lutz, São Paulo, v. 62, n. 2, p. 131-133, 2002. DOI: RIALA6/929.

SANTOS, P.; AGUIAR, A. C.; BARBERO, G. F.; REZENDE, A. A.; MARTINES, J. Supercritical carbono dioxide extration of capsaicinoids from malegueta pepper (Capsicum frutescens L.) assited by ultrasound. Ultrasonics Sonochemistry, London, v. 22, n. 1, p. 78-88, 2015. DOI: 10.1016/j.ultsonch.2014.05.001

SILVA, D. J.; QUEIROZ, A. C. Análise de alimentos: métodos químicos e biológicos. 3. ed. Viçosa, MG: Universidade Federal de Viçosa, 2002. 235 p.

SILVA, R. B. Suplementação de vacas leiteiras com óleos essenciais. 2017. Tese (Doutorado em Zootecnia) Universidade Federal de Lavras, Lavras, MG.
SMITH, D. R.; DILORENZO, N.; LEIBOVICH, J.; QUINN, M. J.; HOMM, J. W.; GALYEAN, M. L. Effects of sulfur and monensin concentrations on in vitro dry matter disappearance, hydrogen sulfide production, and volatile fatty acid concentrations in batch culture ruminal fermentations. Journal of Animal Science, Champaign, v. 88 , n. 4 , p. $1503-1512$, 2010. DOI: $10.2527 /$ jas.20092498

SURESH, D.; SRINIVASAN, K. Tissue distribution and elimination of capsaicin, piperine and curcumin following oral intake in rats. Indian Journal of Medical Research, Mysore, v. 131, n. 1, p. 682-691, 2010. DOI: PMID20516541

TABELA DE NUTRIÇÃO - TABNUT. Departamento de Informática em Saúde, Escola Paulista de Medicina. Universidade Federal de São Paulo. São Paulo: Unifesp, 2006. Disponível em: http://tabnut.dis. epm. br/alimento/02031/condimento-pimenta-vermelha-oucaiena. Acesso em: 08 set. 2018.

UNIVERSIDADE FEDERAL DE VISOÇA - UFV. Manual de utilização do programa SAEG Sistema de Análise Estatística e Genéticas. Viçosa, MG: Universidade Estadual de Viçosa, 1997.

VALADARES FILHO, S. C.; PAULINO, P. V. R.; MAGALHÃES, K. A. Exigências nutricionais de zebuínos puros e cruzados - BR-Corte. 2 ed. Viçosa, MG: UFV, Suprema Gráfica Ltda., 2010. 193 p.

VALVERDE, R. M. V. Composição bromatológica da pimenta malagueta in natura e processada em conserva. 2011. Dissertação (Mestrado em Engenharia de Alimentos) - Engenharia de Alimentos, Universidade Estadual do Sudoeste da Bahia, Itapetinga.

VAN SOEST, P. J.; ROBERTSON, J. B.; LEWIS, B. A. Methods for dietary fiber, neutral detergent fiber, and nonstarch polysaccharides in relation to animal nutrition. Journal of Dairy Science, Savoy, v. 74, n. 12, p. 35833597, 1991. DOI: 10.3168/jds.S0022-0302(91)78551-2

WINDISCH, W.; SCHEDLE, K.; PLITZNER, C.; KROISMAYAR, A. Use of phytogenic products as feed additives for swine and poultry. Journal of Animal Science, Champaign, v. 86, p. 140-148, 2008. Supplement. DOI: 10.2527/jas.2007-0459

ZEOULA, L. M.; CALDAS NETO, S. F.; GERON, L. J. V.; MAEDA, E. M.; PRADO, I. N.; DIAN, P. H. M. Substituição do milho pela farinha de varredura de mandioca (Manihot esculenta, Crantz) em rações de ovinos: consumo, digestibilidade, balanços de nitrogênio e energia e parâmetros ruminais. Revista Brasileira de Zootecnia, Viçosa, MG, v. 32, n. 2, p. 491-502, 2003. DOI: $10.1590 / \mathrm{S} 1516-35982003000200030$ 
